\title{
Methodology of Comparative Legal Research
}

\author{
Mark Van Hoecke ${ }^{1}$
}

Researchers get easily lost when embarking on comparative legal research. The main reason being that there is no agreement on the kind of methodology to be followed, nor even on the methodologies that could be followed. ${ }^{2}$ Moreover, almost everything that was more or less established in the area of comparative law over the last century has been increasingly criticized during the last few decades: the concept of 'legal family', the possibility of comparison itself, the object of comparison, etc.

On the other hand, comparing domestic law with the way the same area has been regulated in one or more countries has become almost compulsory in doctrinal legal research. Also in legal practice, globalization and most notably Europeanization involve comparative research.

How should a comparative researcher cope with this apparent paradox?

In this paper, an attempt is made to work out a methodology for comparative legal research, which goes beyond the 'functional method' or methodological scepticism.The starting point is the idea that we need a 'toolbox', not a fixed methodological road map, and that a lot of published, but largely unnoticed, research outside rule and case oriented comparative law offers varying approaches, which could usefully be applied in comparative research. Basically, it is the aim of the research and the research question that will determine which methods could be useful. ${ }^{3}$ Moreover, different methods may be combined, as they are complementary and not mutually exclusive. This paper focuses on scholarly comparative legal research, not on the use of foreign law by legislators or courts, but, of course, the methodological questions and answers will largely overlap.

1 Professor of Comparative Law at Queen Mary University of London, and Professor of Legal Theory and Comparative Law at Ghent University.

2 This chaotic and unscientific situation has been well described by Esin Örücü: "There are comparative lawyers who see comparative law as a science with its own separate sphere. Others call comparative law merely a method of study and research or even a technique. Some regard it both as a comparative method and a comparative science of law, or see in comparative law more than one of these aspects. It is immediately obvious that those who see comparative law as a method only do not tell us what that method is, leaving this issue unanswered or very vaguely covered, and those who think or feel that comparative law must be more than a mere method do not seem to agree on what this subject-matter is." (Örücü 2007, p. 62)

3 In the same sense: Adams \& Griffiths 2012 , p. 279-301; Örücü 2006, p. 450-451. 


\section{Why compare?}

At the end of the nineteenth century and early twentieth century, in France, Raymond Saleilles and others saw comparative law mainly as an instrument for improving domestic law and legal doctrine, as a way to renovating the fossilized approach of the still dominating Exegetic School to the Civil Code and its interpretation (Saleilles 1911, p. 22). ${ }^{4}$

By the end of the twentieth century, many legal scholars in Europe considered comparative law to be the necessary instrument for a (desirable) harmonization of law within the EU.

Hence, according to the circumstances, there may be different aims and diverging reasons for comparing legal systems.

In a general way, Patrick Glenn has answered this question under the heading 'Aims of Comparative Law'. ${ }^{5}$ He lists (a) comparative law as an instrument of learning and knowledge ${ }^{6}$ (information on the law elsewhere and a better understanding thereof), (b) comparative law as an instrument of evolutionary and taxonomic science (common evolutions, diachronic changes, legal families), (c) contributing to one's own legal system (understanding it better, including the resistance of its traditions, improving it, using it as a means for interpreting the constitution), and (d) harmonization of law. However, Glenn strongly criticizes much of the ideology that underlies traditional comparative law and largely still does today. There is the constructivist belief in the use of foreign law for one's own, otherwise nicely protected, national legal system, or in harmonizing law being just a technical matter, or in taxonomies of coherent 'legal families'. There is also a lot of Western imperialism in what William Twining has called the 'Country and Western approach' of comparative law (Twining 2007, p. 69-89). Nevertheless, even in a more open, pluralist and less constructivist comparative research, the mentioned aims are still largely valid, Glenn concludes.

In concrete comparative research projects, it is the aim of the research and the research questions that will imply some form of comparative law (or not). If the aim of the research is making some part of the domestic law more coherent one may well do without any external comparison. If the aim is to harmonize the law, e.g., within the EU, comparing the legal systems involved is already implied by this aim, but also the approach to be followed is partly determined by it, as the

4 See also the debate in the US on citing or not foreign case law, which in its turn is located within the discussion between 'originalists' (following the historical meaning of legal texts) and 'evolutionalists' (wanting to adapt the text to changed circumstances) (Reed 2008, p. 253-273).

5 In the Elgar Encyclopedia of Comparative Law (Glenn 2006). Compare the 'purposes of comparative law research' as listed by Esin Örücü (2007, p. 53-56).

6 Compare: 'Comparative law is like other sciences in that its aim must be the acquisition of knowledge. Like other branches of legal science, it seeks knowledge of law' (Sacco 1991). Sacco is also referring to Zweigert and Kötz, who in their Introduction to Comparative Law use a similar wording (he refers to the pages 16-17 of the second edition of the German version of 1984). 
focus will be on the commonalities, on the common core of the compared legal systems and on the possible ways of erasing differences.

When one tries to improve one's own legal system, be it as a legislator or as a scholar, it has become obvious to look at the other side of the borders. However, importing rules and solutions from abroad may not work because of a difference in context. Hence, a more thorough contextual approach may be required.

One may also want to inquire to what extent a legal evolution in one's own country finds parallel developments in other countries. A paramount example is the developments in family law, mainly in Europe, over the last half century (see e.g., Antokolskaja 2007; Boele-Woelki, Dethloff \& Gephart 2014).

When comparing official state law in African countries with local customary law, one will notice that they show a tension between tradition and modernity, between Western law only followed by an elite and African law as the large majority of the population perceive it. Hence, an anthropological approach that puts the law in context will be necessary for explaining this tension, for understanding it and for finding solutions for it.

If one's research question would be whether the position of the notary public in some continental European country could be abolished and replaced by a civil officer or by a practising lawyer (advocate), it seems rather obvious to have a look at the common-law countries where such a specific profession doesn't exist.

All scholarly research implies comparisons. Scholarly legal research often requires comparing one's own legal system to another one. Here, we will focus on comparing national legal systems, as this is the most common geographical level of comparison.

\section{Choice of legal systems to be compared}

Comparative research is still mainly about comparing national legal systems, even if different forms of globalization, such as Europeanization, and an increasing recognition of non-state law, such as customary law, religious law or unofficial law-making by international companies are challenging the very concept of 'legal system'. Here, we are not entering into that discussion (Van Hoecke 2014, p. 43-57). In practice, when choosing national legal systems to compare with, most (individual) researchers will make a choice on the basis of their knowledge of languages, which explains why most comparative research in the Anglo-Saxon world is focusing on comparing common-law countries that still use English as their (main) official language. ${ }^{7}$ This makes comparative research in most areas of

7 See eg: Flanagan and Ahern 2011. Of course, such research has its value and for the purpose of this article (judges citing foreign law as a source of persuasive authority) it even makes sense to limit the research to the countries involved, as in many countries supreme courts will never cite any persuasive authority (even if they may have used it) but only the law they apply. However, the results of a comparison among Common Law or English language countries may only create a false impression of universality. In the mentioned article the survey covers courts from Brit- 
the law quite easy, as the whole conceptual framework and the older history of the common law is also the same for all legal systems compared. However, such research may be useful at the informative level, for businessmen for instance, but is not entirely useful in the context of broader scientific research.

Increasingly, some translations of legal texts in English are available for most countries all over the world. However, they tend to cover only legislation and do not always follow changes made to the law, so that they may rapidly be outdated. The same goes for general introductions in English, to the law or a specific area of it, of individual countries. It may be desirable to use such information in some cases, for instance as a confirmation of what has been found elsewhere, but for a thorough comparative research a good reading knowledge of the local language ${ }^{8}$ is an absolute requirement. Even for a limited use of English language publications on the law of a country of which the researcher cannot read the local language, it is highly recommended to check whether one's own interpretation is correct and whether there have been any recent changes in that law, by contacting a local scholar who speaks English or another language the researcher masters. For this, a well-elaborated network of colleagues in the same area of law is very valuable.

Even when one's knowledge of languages will be the prime reason for choosing or eliminating some country, the researcher should be able to give good reasons why her choice is acceptable from a scholarly point of view. For instance, when studying the division between public law and private law, it makes sense to focus on France and on the UK, as they may well have the most opposed views on the matter. This may be used as a strong argument, so that the researcher may leave aside her initial problem that French and English may be the only two languages she knows.

For larger projects, an international team, that masters together all required languages, may be the solution, on the condition that the internal communication within the group is sufficiently intense and qualitatively good. Every member of the team should be able to detect the relevant commonalities and differences between the studied legal systems and their contexts, and, moreover, be able to explain them clearly to the other members of the team. In the case of such teams the choice of legal systems to be compared may be based on more relevant criteria than the accidental (lack of) knowledge of languages of individual researchers. However, one has to be aware that lack of sufficient understanding of foreign legal systems may arise from an imperfect communication within the team.

It is also risky to involve legal systems with legal cultures one is not familiar with, at least to some extent, at the start of the research project. Assume that a research team wants to set up a worldwide research project on divorce. For this, they draft

ain, the Caribbean, Australia, South Africa, Ireland, India, Israel, Canada, New Zealand and the United States, in other words, countries from all continents.

8 In case of indigenous or other customary laws with an oral tradition it will, of course, have to be a sufficient access to the spoken language. 
a lengthy questionnaire with all kinds of questions on the grounds for divorce, on the procedure and on the legal consequences of each type of divorce. After this, they contact their network for answering those questions. However, the response will be largely biased if they based the questionnaire on Western law only. Indeed, it will not take into account the 'repudiation' of a wife under Islamic law, which sometimes has been equated to 'divorce by mutual consent' in Europe. It will not take into account traditional marriage in African countries, where legislation only regulates 'official' (and monogamous) marriage, even if traditional marriage, concluded according to customary law, is accepted. This customary marriage largely doesn't include the concept of divorce, nor is there a need to do so in view of the (unlimited) polygamy set-up. This means that, before setting up a large comparative research project of this kind, one has to define different levels of comparison, on the basis of such elements and their correct understanding. One cannot study divorce inter-culturally without a broader understanding of marriage, of the role of families, of the general attitude to divorce in each of the compared societies.

The wording of the research question will be the main criterion for the choice of legal systems to be compared.

If, for instance, one wants to inquire to what extent the law on contracts for renting houses or flats could be harmonized within the European Union, the law of the 28 member states will have to be studied. However, if the working hypothesis would be that such harmonization is not possible, it may suffice to study two legal systems, such as the French and the English one, if one may prove that harmonization between those two legal systems would be impossible and, hence, any harmonization within the whole of the EU.

If one would like to study the role of the king or queen in kingdoms worldwide, or the way federal states are organized, one should in principle involve all legal systems that are relevant for this topic. In practice, however, a much more limited selection of countries may still be quite relevant and, hence, suffice. Comparing, for instance, just the US and Germany may allow to go deeper into the historical developments which explain the current situation and into the way these federal structures work in practice. If one wants to challenge the concept of 'federal state' itself, a comparison with the structure of the European Union may look quite attractive.

Another approach may be to look first at the reasons for a more decentralized organization of a country: historical coincidence, making the practical organization of a large state feasible, living together of various communities with different languages, religions, and/or cultures within the same state, etc. If one wants to inquire how, for instance a federal structure, or some specific parts of it, has contributed to a peaceful living together of people within the same state, it may be more relevant to compare, for instance, Belgium, Canada, and Nigeria than the US and Germany. 


\section{What has to be compared?}

In the nineteenth century, associations and journals were founded on 'comparative legislation'. At that time, there was a focus on comparing rules in different societies. ${ }^{9}$ Later on, more attention was paid to judicial decisions and the way legal problems were solved in practice. ${ }^{10}$ Meanwhile, many authors on comparative law emphasize also the importance of taking into account the socio-economic and historical context of the law when carrying out comparative legal research. Where has the comparative researcher to look for in foreign legal systems: legislation, and/or case law and/or their entire context? Relevant legislation and (published) case law may be found relatively easily. In the first place, in doctrinal books and articles (much less in Italy, however, where legislation is often discussed without direct references to case law) and, for more recent months and years, through electronic databases. But what to do with the context of the law? Occasionally, some explanations may be found in doctrinal legal writings, but until now this has been rather exceptional. Sometimes it was explained widely in the international press, such as the financial crisis as the context and explanation for some domestic and European changes in regulations of the financial sector. Sometimes, the researcher may discover historical, sociological, and/or economic literature on her topic for a country included in the comparison, but that is not obvious either. Whereas some limited social science research may be feasible within the context of one's own legal system, for foreign countries this will, as a rule, be excluded within the frame of research in law carried out individually. Much will depend on the focus of one's research and on the available sources. A good balance between both will guarantee the feasibility of the research design. An overly ambitious law-in-context approach for a topic where there are insufficient available sources will make the research plan unrealistic within the context of comparative legal scholarship.

In short, comparing only legislation is risky when there is no information available on how it works in practice, and such a limited comparison is only acceptable for countries which are not at the core of one's comparative research. For instance, when comparing one's domestic law with German law, the researcher may add

9 The idea was also to find the 'ideal legislation'. It was an approach to comparative law based on natural law: '...consciously or unconsciously, it postulates natural law of the old rationalist type. It tacitly assumes that for every detail of every legislative problem there is one right universal rule, which the lawmaker is seeking to discover and to formulate. (...) The expert on comparative legislation combines the information afforded by the legislation of the world on any point you like and pulls out the one right rule' (Pound 1936, p. 57).

10 In France, in the early $20^{\text {th }}$ century, most notably Raymond Saleilles and Edouard Lambert criticized the work of the Société de legislation comparée, which simply translated foreign legislation without taking into account how it worked in practice. These authors assumed that 'real life' was to be found in case law (Saleilles 1891, p. 219). Lambert was even opposed to using social sciences, which were at that time not sufficiently developed to be able to offer enough precise and useful information for comparative law (Lambert 1900, p. 237). 
that the legislation is the same in Switzerland and/or in Austria, without making a thorough analysis of those legal systems in relation to this point.

Comparing case law (and legislation) will require some knowledge of the historical and socio-economic context that transpires from the available sources. When comparing neighbouring countries, the researcher may have a general idea of historical and/or socio-economic similarities and differences. For differences, some better insight into that context will be required. Also, focusing on practical solutions to legal problems should not dissociate the legal solutions from their doctrinal context, as some solutions may be accidentally similar, which may hide more important differences at the level of the concepts used and the systemic building of that area of the law.

Fully comparing law-in-context within individual research will only be possible if one is lucky to find sufficient relevant sources and literature for each of the legal systems to be compared.

Otherwise, team research will be required, preferably with an interdisciplinary team. Again, some rough understanding of differences and similarities between the legal systems, and of the relevant context for explaining them, will be a prerequisite for setting up the research project and selecting not only the legal systems to be compared, but also the disciplines relevant for the context research. When comparing banking law, for instance, one may assume that economics is most relevant for explaining similarities and differences, but maybe history and/or psychology would eventually appear to be even more relevant for the specific research question. With inter-cultural comparisons, apparent similarity of (imported) legislation, e.g., on the equality of men and women, may hide a completely different reality. Only (legal) anthropological research may reveal and adequately explain this. In all cases, however, comparison should never stop at the level of legislation, and even not at the level of case law, as the social reality may be more different than similar rules suggest (and sometimes more similar than different rules would suggest). Rules may exist on paper, but are not applied in practice. Absence of case law on the matter may have diverging explanations: (a) everybody follows the law; (b) the matter has been settled for a long time (e.g., unchanged legislation as to real estate for many decades, if not centuries) and, hence, there are nowadays few disputes that end up in court and/or the judicial decisions are not interesting from a doctrinal point of view and are, therefore, not published; (c) victims of illegal practices don't dare to go to court because of strong social pressure (e.g., in cases of rape); (d) problems and conflicts are (almost) always solved outside the law or outside its institutions; etc. In all those cases, lack of sociological inquiries may lead to a completely distorted view on the law in a foreign country. Lawyers generally will have a basic understanding on these points as to their own law, but mostly not, or at least not to the same extent, as to foreign legal systems. 


\section{How does one compare?}

Comparative law has often been criticized for not following any method when carrying out comparative research. Indeed, comparatists often act like tourists who visit a foreign city and notice that things are different, be it to some extent similar too, compared to their home-town. After their visit they will be able to describe what they have seen to their family and friends at home, but they will lack a more general framework used, for instance, by specialists in architecture or art historians to describe the same sights in a (very) different way. Comparative researchers should become professionals rather than be tourists. However, the theoretical framework historians and architects may dispose of is still largely lacking for comparative law. Whereas legal scholars have been educated with a firm doctrinal framework for their own legal system, they lack such an overarching framework for comparative research.

Sometimes 'comparing' is considered to be a 'method' in its own right and called 'the comparative method' without further explanation or concrete guidelines. The only 'method' proposed in comparative literature, which goes one step further, is the so-called 'functional method'. It offers one concrete guideline in that it suggests to focus on (common) legal problems and legal solutions in the compared legal systems, rather than on the (diverging) rules and doctrinal frameworks. However, some elements for other comparative methods may be found in the literature, mainly in the area of legal theory. On the basis of these writings, we may distinguish six different methods for comparative research: the functional method, the structural method, the analytical method, the law-in-context method, the historical method and the common-core method. Probably they constitute together the whole toolbox for comparative research.

Following Berthelot, Geoffrey Samuel has distinguished six different 'schemes of intelligibility': causal, functional, structural, hermeneutical, actional and dialectical. They are, according to Berthelot and Samuel, to be identified as separate epistemological readings in that not one of the six can be reduced, in terms of its fundamental logical relations, to one of the others. ${ }^{11}$

Hereafter, we will discuss the functional method and the structural method in the context of comparative research, next to the analytical method, the historical method, the law-in-context method and the common-core method. The latter methods are not mentioned among the six distinct schemes of intelligibility in the context of the social sciences in general, but we may see them as combinations of two or more of them. Causal understanding, for instance, has a pivotal role to play within the law-in-context approach and the historical method. Hermeneutics, in its turn, is vital to all comparative methods. 
The different 'methods' discussed hereafter are not mutually exclusive. It is even possible to combine all of them in one and the same research. The name of the method points to the specific feature of that approach, without excluding its combination with another method.

\subsection{The functional method}

Following Zweigert and Kötz and their popular introductory book on comparative law, it is often taught at universities that 'the' method of comparative law is the 'functional method', optimistically supported by the alleged conclusion that rules and concepts may be different, but that most legal systems will eventually solve legal problems in a similar way. ${ }^{12}$

Apart from the conclusion that both authors never seem to have elaborated, or even applied, this 'method' themselves, the 'functional method' and its underlying 'praesumptio similitudinis' have increasingly been criticized in recent years.

Ralf Michaels, summarises his critical analysis as follows:

"In short, "the functional method" is a triple misnomer. First, there is not one ("the") functional method, but many. Second, not all allegedly functional methods are "functional" at all. Third, some projects claiming adherence to it do not even follow any recognizable "method"' (Michaels 2006, p. 342). ${ }^{13}$

Indeed, 'functionalism' is used in quite diverging meanings, serving rather different goals: understanding law, comparing (tertium comparationis), focusing on similarities (praesumptio similitudinis), building a system (of 'legal families', for instance), determining the 'better law', unifying law, critical appraisal of the legal orders (Michaels 2006, p. 364-380). This variety of 'functional methods' points to the importance of the research aim and research question for choosing an appropriate comparative method. Basically, what the researcher will compare and how, largely depends on the research question(s) and research interest. The method followed should serve that goal. The idea behind functionalism is to look at the way practical problems of solving conflicts of interest are dealt with in different societies according to different legal systems. This allows us to perceive those problems (largely) independently from the doctrinal framework of each of the compared legal systems (Husa 2011, p. 221-222). Many societal problems, such

12 The functional approach had been introduced to comparative law several decades earlier, partly along the line of fashionable 'functionalist' trends in other disciplines. In 1936, Roscoe Pound defined a 'functional comparison' as the 'study of how the same thing may be brought about, the same problem may be met by one legal institution or doctrine or precept in one body of law and by another and quite different institution or doctrine or precept in another' (Pound 1936, p. 59). In 1924, Ernst Rabel noted that solutions to contractual problems were largely the same in England, France, and Germany, notwithstanding quite different legal constructions of that field (Rabel 1924). According to Michele Graziadei the functional method would have its roots in $19^{\text {th }}$-century international private law (Graziadei 2003, p. 103ff). Max Rheinstein, in his turn, considered Edouard Lambert to have been the 'first conscious exponent' of the 'functional approach' around 1900 (Rheinstein 1934-35, p. 250).

13 Jaakko Husa (2013) shows how 'functionalism' in comparative law has little to do with 'functionalism' in other disciplines. 
as accidents, family problems, theft, murder, quarrels between neighbours, etc., are to be found in most, if not all, societies. All societies have some form of 'law' which helps to solve those problems. Legal concept, legal rules and legal procedures may sometimes rather diverge, but still the solutions given to some problems may be similar or even identical. In other words, the legal solution may be the same, notwithstanding the diverging roads used to reach that solution. The functional method is looking for such 'functional equivalents' at the level of the solutions. If, in view of the research question, such as 'Which solution is given in countries A, B and C to legal problem P?' or 'Which institution in system B performs an equivalent function to the one under survey in system A?' (Örücü 2006, p. 443). ${ }^{14}$ only the result counts and if this legal solution is the same in the compared countries, then the researcher may conclude that the law is 'the same' in those countries. However, if the focus is on the way in which the legal rules and doctrinal constructions of the respective legal systems solve that legal problem, the functional method is not very relevant.

Moreover, in some cases similar or identical rules in two compared legal systems lead to diverging results. ${ }^{15}$ This is a kind of functional 'dis-equivalence'. Here, focusing on the rules only would not be very useful.

In the same chapter, Ralf Michaels rightly points to the conclusion that 'at least three main current approaches other than functionalism remain: comparative legal history, the study of legal transplants, and the comparative study of legal cultures' (Michaels 2006, p. 341). However, the first one has a strong historical dimension, the latter an anthropological one, and the study of legal transplants a sociological one, as it studies how rules and concepts may (not) work in a different socio-economic environment (apart from a different doctrinal environment). Functionalism, for its part, is often used with the (implicit) assumption that problems are the same everywhere (theft, car accident, failure of executing a contract, etc.). This may be true in many cases in countries with a similar historical and socio-economic background (the Western European countries, for instance), but even then not in all cases and certainly not in all countries and legal cultures worldwide. Moreover, different doctrinal structures may 'create' different problems, complicate or facilitate them being solved. Hence, proponents of the functional method try to limit the comparison to 'universal facts', like two cars hitting each other at a crossroad, leaving aside whatever is determined by the local law or legal culture (See on this: Graziadei 2003, p. 108ff). However, in this way not much may be left for a functional comparison. Indeed, functionalism cannot isolate the solutions to practical problems from their doctrinal legal framework (including procedural rules), and it cannot separate those problems from their socio-economic and historical context.

15 Typical examples may be found in the countries, such as Belgium, which kept or took over the Code Napoléon after Napoleon's defeat in 1815 but interpreted unchanged articles of that code in a different, and sometimes even opposed, way, compared to France. 
In its most common understanding, the functional method doesn't compare primarily rules, but solutions to practical problems with conflicting interests. It is true that there are relatively universal human attitudes to certain situations, such as taking care of children, respecting property rights, executing contractual obligations, compensating in one way or another damages caused by one's wrongful conduct, and so on. Hence, practical solutions to similar problems in those areas in different legal systems will often more converge than the legal roads used to reach those results. Canon law, for instance, doesn't encompass divorce. Nowadays, all countries with a Christian tradition offer the possibility of divorce in their legislation. In practice however, the Roman-Catholic Church is quite flexible as to declaring a marriage void, whereas this is much more difficult in the state legal systems. There are still important differences between state laws and canon law, but the practical answers to problematic marriages diverge less than the differences in divorce legislation would suggest. As a result, the functional method helps the researcher to broaden the scope of her research. Indeed, similar results are often reached following different roads, or too harsh consequences of too strict rules are attenuated by other means. By focusing on practical problems and their solutions, one may discover those different legal roads. Actually, law is a way to structure reality. Different cultures may use different ways to structure similar realities, but partly they also create different realities.

Hence, the functional method has to be complemented by other methods.

What makes functionalism easier than the other 'methods' listed, is that it requires a less thorough analysis of the broader cultural context, if any, and, hence, is more accessible to the average legal researcher. It reduces the complexity of comparing legal systems in a very attractive way for most researchers

The price paid for it is that the explanatory force of research using the functional method is more reduced and that more creative work can be done, e.g., in comparative legal history, or using the law-in-context method.

\subsection{The structural method}

Functionalism typically applies at the level of micro-comparison. From a broader perspective a more structural analysis of (parts of) legal systems may be used. When discussing this approach in social sciences in general, but presenting it as an alternative to the functional method in comparative law, Geoffrey Samuel notes:

'This is a grille de lecture whereby the observer focuses on the structures hidden within the phenomenon being observed. These structures can be loose in the way they interrelate (for example plot structures in literature) or they can be a collection of elements that form a system, this latter notion being characterised by the creative interaction of the elements within a totality that can be identified as having frontiers and thus being independent' (Samuel 2014, p. 81-82). 
When elaborating classifications of 'legal families', a structural approach has been underlying them. Differences between legal systems at the level of concrete rules become irrelevant if they share enough structural commonalities, such as Roman law principles and concepts in private law, to classify them as members of the same 'legal family', as opposed to other legal systems and families which do not share those commonalities. Of course, the selection of the most relevant criteria for determining 'similar structures' partly determines the outcome.

Example: assume one wants to compare land law worldwide and to try to classify them into 'legal families'. The obvious starting point will be to follow the traditional distinction between the 'Anglo-Saxon' and the 'Romano-Germanic' legal families. However, one may prefer to start from the distinction between public or rather private law governing the matter: in the so-called 'socialist' or 'communist' regimes in Eastern Europe during several decades in the twentieth century disposing of means of production (ownership) was a matter of public law, whereas in most other countries it was a matter of private law (mainly ownership or rent). From another point of view, one might consider that a basic distinction is the one where the state owns all the land and citizens have more limited rights than full ownership, even if they may be the proprietor of the house they have built on it. When using this criterion, it would bring together countries such as the United Kingdom ('The Queen owns all land'), the Democratic Republic of Congo (citizens may obtain an 'eternal' concession on the land, companies and foreigners only a concession for 25 years), and the People's Republic of China (the state owns all land, but not necessarily the buildings built on it). Nevertheless the legal systems of those countries wouldn't be considered to belong to one and the same legal family, when looked at from almost any other perspective. However, there is no 'objective' reason why this criterion would be less relevant compared to other criteria.

Everything depends on the underlying theory. If the worldwide dominant paradigm accepts the distinction between the Romano-Germanic family and the Anglo-Saxon family as the most vital one, the criterion of the state ownership of land as opposed to full private ownership may still be useful for the selection of legal systems for some micro-comparison, but it will not be accepted for classifying legal systems worldwide.

Also, the traditional 'legal families' classifications assume that one specific criterion or structure may be considered decisive for classifying the totality of each legal system into one and the same family. However, as all these classifications are based on private law only, it is obvious that a public law classification may lead to quite different results, again depending on the criteria used (kingdom or republic, federal or centralized state, direct elections of the key governing bodies or not, states with or without a constitutional court, degree of respect of human rights, etc.). Within private law, one may also argue that it is not possible to make one overall classification, but that a further distinction has to be made (family 
law, land law, inheritance law, labour law, etc.). If this would be accepted, it would throw a different light on our example of the ownership of land. Suddenly, bringing together the UK, Congo and China into one legal 'land law' family, wouldn't only sound reasonable but even quite convincing.

Structural analyses may be made in many different ways, on the basis of a large variety of distinctions and criteria. At the most basic level one could actually argue that all legal systems structurally have a common core, which is linked to the definition of law as an identifiable system in any society. One such basic distinction typical for all legal systems is the presence of (primary) rules of behaviour and, in addition, secondary rules that govern the coming into being and the application of those primary rules (Hart 1961, p. 77-96). Joseph Raz has argued that, at the level of the secondary rules, there is some minimum content which is common to all legal systems:

'The minimum content and the minimum complexity of all legal systems, together with the principles of individuation, determine the necessary internal relations existing in every legal system, that is the internal structure which is necessarily common to all legal systems' (Raz 1980, p. 141).

As a result, it should be possible to identify those secondary rules in every legal system and compare them as to the competence for law making (who has the power to make law or to change the law?) or for legal adjudication (who has the power to (finally) decide about the application of the law?). Moreover, in developed legal systems, all this has to happen through specific procedures. So, the question as to the procedures for law making and for the adjudication of the law are also relevant for all legal systems. Of course, in more primitive legal systems those functions may be mixed up (e.g., the chief of the tribe being both competent for making law and applying it) and the procedures may be very limited. Hence, the degree of development of such procedures and the degree of separation between law making and the adjudication of the law may offer a comparative criterion for classifying legal systems at the level of their secondary rules.

\subsection{The analytical method}

Well known in the Anglo-Saxon legal world, but less in the rest of the world, is the analysis of the concept of 'right' by the American law professor Wesley Newcomb Hohfeld (Hohfeld 1919). He noticed that the concept of 'right' is used in several different meanings. It may mean a 'claim', a 'power', a 'liberty', or some other legal concepts, which he calls 'immunity' (escaping from someone else's legal power) and 'privilege' (an exception to a more general prohibition). This refinement of the concept of 'right' was an important step forward in analysing the 'deep structure' of the concept of 'right' and in clarifying the actual meaning of this word, as used in several different contexts. Moreover, and most importantly, he studied the logical relation between the different sub-concepts of 'right' and other concepts, such as 'duty' or 'liability'. For example, if one has the right to do A, there can be no duty not to do A. Hohfeld distinguished 'legal opposites' (one cannot have at the same time a right and non-right on the same object, or a privilege and a duty 
as to the same behaviour) and 'legal correlatives' (when A has a right against B, then B has a correlative duty towards A) (Hohfeld 1919, p. 36).

Here, we are mainly interested in the analytical force of such a distinction for comparative law. Many legal concepts, in all legal systems, contain a bundle of 'rights' of a different kind. 'Property', for instance, includes a claim (of non-interference), a liberty (to use) and a power (to transfer the property rights partly or fully). By looking at this deeper level we may better distinguish differences and commonalities between legal systems as to apparently similar or different concepts (e.g., 'ownership' of land vs 'fee simple absolute in possession', 'easement' vs 'servitude', 'mortgage' vs 'hypothèque') used in each legal language. A broad concept such as 'trust' in the Anglo-Saxon tradition is unknown in Continental Europe. ${ }^{16} \mathrm{How}^{-}$ ever, upon a closer look, it appears that, depending on the context, rather similar constructions may sometimes be discovered and clear differences at other times (e.g., the power of the creditor in some cases to seize money directly with a third person, as if it were his property ('imposed trust'), which is impossible on the Continent). Only at the deeper 'Hohfeldian' level, adequate comparison between the 'trust' and continental legal concepts and constructions becomes possible.

Brouwer and Hage believe that, by using the Hohfeldian analysis, or another of that kind, 'the private law of the different European countries can be reconstructed in terms of a limited set of the same basic concepts' (Brouwer \& Hage 2007, p. 4). According to them, such a set of basic concepts should allow for correct representations of the contents of private law and render it comprehensive and non-redundant (Brouwer \& Hage 2007, p. 7). Characteristic of a basic concept is, moreover, that it cannot be specified in terms of other, more elementary concepts (Brouwer \& Hage 2007, p. 12). For Brouwer and Hage there are only two basic legal concepts in private law: 'duty' and 'competence' (p. 18ff).

The above mentioned examples also point to the conclusion that it is not possible to disconnect concepts from the rules of the legal system to which they belong. The content of a legal concept is defined by the actual rules governing the field covered by the concept, within a particular legal system at a specific moment of time. However, sometimes these are minor differences, and some common core may be detected, with concepts such as 'will', 'ownership', 'state', etc. For this reason, Åke Frändberg made a distinction between concepts that are 'system-dependent' and concepts that are (relatively) 'system-independent' (Frändberg 1987, p. 88-91). He proposed to work with 'ideal types' of such concepts. ${ }^{17}$ According to Hedenius, as noted by Frändberg, a system-independent definition of 'ownership' contains

16 It is interesting to note that after several legislative experiments in Russia in the 1990s with the introduction of the concept of trust 'lawmakers and the majority of Russian civil law academics rejected the Anglo-American trust' (Zhdanov 2006, p. 182). What is currently called the 'Russian trust management' is a contractual obligation and doesn't have much in common with the Anglo-American 'trust', which is a property law concept (Zhdanov 2006, p. 182).

17 Following Max Weber. Brouwer and Hage call them 'stereotype concepts', following the terminology proposed by Hilary Putnam (Brouwer \& Hage 2007, p. 11). 
two elements: 'protection of possession' and 'freedom of disposal'. The 'ideal type' of 'ownership' (in a technical sense, not a normative one) is one with a total protection of possession and an absolute freedom of disposal (Hedenius 1975, cited by Frändberg 1987, p. 83ff). All actual concepts of ownership in the different legal systems may be defined on a scale of more or less protection of possession and more or less freedom of disposal. Combined with a Hohfeldian analysis, this approach may probably be refined, but the idea of using 'ideal types' in comparative law should certainly be fruitful.

A thorough analytical approach may, eventually, offer in its turn building blocks for a structural comparison of legal systems.

In 1973, André-Jean Arnaud published his Essai d'analyse structurale du Code civil français. In this book, Arnaud aimed at 'decoding' the Code Napoléon, at drawing its 'eucledian geometry'. As regards, for instance, the law of obligations, he discerns 'jural opposites', such as voluntary/involuntary, action based on the law (legislation) or on an act (e.g., a contract), a duty to give or to do (including not to do), a duty to give a thing or to give money, equilibrium or not, reciprocity or not, etc. (Arnaud 1973, p. 94-125). When revealing the deep structure of the (French) law of obligations, he finds a taxonomy with, as a grand total, 32 possible or even imaginable relations (Arnaud 1973, p. 122) ${ }^{18}$ Arnaud concludes that his opposites do not exactly correspond to the 'official' opposites, as used in the Code (for example: synallagmatic/unilateral, aleatory/commutative), but that they offer a conceptual framework which is fundamentally valid for the law of (civil) obligations in any legal system (Arnaud 1973, p. 121). Whether this is correct has still to be checked, but at least it has the advantage of offering a structure built on the basis of an analytical research in one legal system with, as a working hypothesis, its validity for any legal system. If this were true, even only partially, this might be an important building block for the methodology of comparative law, as it is not just offering concepts, but a whole structure covering a whole field of law, a kind of Table of Mendeleev for the law of obligations.

The most ambitious attempt to determine the 'legal grammar' of legal systems in view of their analytical and structural comparison is to be found in the work of Leopold Pospisil (1971). As an anthropologist of law, he tried to work out a model that could be used for cross-cultural comparison, valid for both primitive societies and developed modern legal systems. Being well aware of the important role of ideology in law, which is most visible in cross-cultural comparison, he emphasizes the need for 'a comparative analysis of basic "jural postulates", derived from the culture and its institutions in general, on the one hand, and legal values, abstracted from the ius as implied in legal decisions, on the other' (Pospisil 1971, p. 345). At a second stage, he worked out an analysis in terms

18 Also Marie-Laure Izorche has proposed to compare legal relations, not just legal concepts and legal rules, firstly within a legal system and secondly between legal systems (Izorche 2001, p. 304-311). 
of 'legal correlates', which should present the subdivisions of a legal concept or field in a logical, systematic, succinct and complete way. Again, the aim is to get a better understanding, at this deeper level, of the similarities and differences amongst different legal concepts and regulations. Pospisil, for example, has thus structured all different forms of terrain ownership amongst the Kapauku tribe in Papua New Guinea in the 1960s. For this, he used opposites, such as 'owned by an individual' or 'owned by a group', more or less exempt from control by others, limitations or not of rights to trespass. Some of the opposites he described, however, are clearly culture bound, such as the right to gather frogs or hunt 'non rats' (Pospisil 1971, p. 295). Pospisil called the systematic set of such jural opposites the 'legal grammar' of the analysed systems (Pospisil 1971, p. 346).

One may doubt whether such a complete model may be worked out for comparing legal systems in quite different cultural contexts, but combined with the methods discussed in this paper it may be useful for understanding very different legal relations and conceptual frameworks in other cultures and for determining the most adequate level for comparing rather different legal systems.

\subsection{The law-in-context method}

All legal scholars will agree that comparative research cannot be limited to pure black-letter comparison of legal rules, concepts or systems. Even domestic legal doctrine will at least take into account the way the law works in practice, as far as it transpires from judicial decisions. On the other hand, law-in-context as a method cannot be isolated from the other methods. They are complementary and interdependent for an adequate understanding of the law. Whereas some forms of the analytical method could be carried out at a more abstract, conceptual level, rather disconnected from the underlying social reality, this is not the case with the other ways of comparison. The functional method refers already by definition to a context: which societal problem is solved with what kind of legal construction? If a society wants its citizens to act responsibly and carefully, so as to avoid to create damages to others, it may use tort law, contract law, statutory obligations, 'subjective' or 'objective' liability, accept 'pure economic loss' or not, etc. In different legal systems and situations legislators (or judges) may have chosen diverging means to reach such an end. In order to guarantee the payment of damages they may have introduced compulsory insurance or other ways that should lead to a balanced redistributive justice, as conceived in the world view of (the majority in) that society. Hence, the functional method is at least to some extent including a law-in-context method. ${ }^{19}$

From several examples above, it appears that the structural method and most of the analytical method cannot be carried out without some minimum law-incontext approach, even if in practice it is often more hidden than made explicit. 
There is a whole range of possible law-in-context methods of research. One may just point to some generally known context element, such as the liberal economic world view underlying the European Union; one may use data from historical, sociological, anthropological, psychological, etc. research, or even carry out such research oneself; one may set up a large interdisciplinary comparative project in which several non-legal disciplines are brought together. Much will depend on the focus of the research and on the available knowledge with the involved researchers, time and financial means when choosing the type and size of the law-in-context approach. In his law-in-context approach, Rodolfo Sacco has been focusing on the 'legal formants', on what has made the law as it is. In this approach it is notably the legal context which seems to be most important: constitutional and legislative rules, case law, and legal doctrine, but also 'implied patterns' and other hidden elements, such as world views, influencing the way law is interpreted and handled. He calls them 'cryptotypes' (Sacco 1991, p. 384-386): 'Some cryptotypes are more specific, others more general. The more general they are, the harder they are to identify. In extreme cases they may form the conceptual framework for the whole system' (Sacco 1991, p. 386). This 'conceptual framework', which I have called the 'paradigmatical framework' (Van Hoecke \& Warrington 1998, p. 513-520) indeed plays a decisive role in the way law is perceived, interpreted and applied.

Putting law in context aims at understanding the law, as a foreigner to that legal system and, hence, explaining why the law is as it is. Inevitably, this implies empirical observation. This may lead to general explanatory propositions, as emphasized by John Henry Merryman, such as 'developed legal systems contain procedures for controlling administrative legality' (Merryman 1999). These are hypotheses about more universal characteristics of (sets of) legal systems. They should and can be tested against empirical data.

The (different) institutional contexts in the compared countries or societies play an important role in explaining apparent differences in law and legal practice. For instance, Adams, Weyers, and Griffiths showed to what extent the different health care systems influence the legal practice concerning euthanasia (or more exactly, 'medical behaviour that potentially shortens life') (Adams \& Griffiths 2012, p. 293-296). ${ }^{20}$ Referring to Koen Raes, Koen Lemmens pointed to the importance of tax law as an explanation for non-pecuniary losses being widely covered in Belgian law (Lemmens 2012, p. 324).

It should be clear that case law is not always offering a correct picture of the living law in a society. When, for instance, no case law can be found at all in some country, it may mean that the law has become obsolete, that the underlying societal problem has disappeared, but also that earlier problems as to the interpretation 
of the law have meanwhile been settled, so that cases are no longer brought to court, as everybody (or at least their counsellors) knows perfectly how to apply the law. It may also mean that a parallel ordering is governing the case, rather than the law (mafia for instance). Courts are the hospitals of social ordering. Only 'ill' cases come to court. The healthy ones remain invisible in the records of judicial decisions. For an overall account of legal reality, an analysis of court decisions in comparative research should be complemented by some legal sociological research.

Legal sociology, in turn, cannot cover all aspects of reality and should, as far as needed according to the research questions, be supplemented by law and economics, and/or legal psychology and/or other disciplines. Researchers will always have to find a balance between the ideal research design, on the one hand, and what is feasible under the current circumstances, taking into account the restraints as to time, money and available knowledge, on the other.

The current 'empirical legal research' approach, which has become popular in the US and is slowly gaining ground in Europe as well, is a kind of modest legal sociology, without the ambition of creating grand theories, but just aiming at checking implicit assumptions of the law or the effect and efficiency of legislation. It should be obvious that such empirical testing is not only useful but very desirable or even necessary. In some cases a broader comparative scale, that transcends the borders of one single legal system, may offer more reliable information, compared to purely domestic research. ${ }^{21}$

Empirical investigations in comparative research will be carried out using one or more of the varying methods known in the social sciences. Mainly qualitative methods will be used, but increasingly attempts are made to use quantitative methods in legal research. ${ }^{22}$ Here we cannot go into detail on this point.

\subsection{The historical method}

Actually, the historical method is just one part of the 'law-in-context method', the context being here the historical origins of the present-day laws, which are compared. A specific feature of this historical approach is that its use cannot be avoided in any comparative research. Fully understanding the law as it functions today in some society, is only possible when one knows where it comes from and why it is as it is today. It is not accidental that also among legal historians 'comparative legal history' has become quite popular over the last decade or so. ${ }^{23}$

21 See e.g. Meuwese \& Versteeg 2012. As to empirical research in comparative law, see also in Adams \& Bomhoff 2012 the contributions by Julie De Coninck, Frederick Schauer, Maurice Adams and John Griffiths.

22 Including in comparative research, see the previous footnote. For a broad and excellent overview, see: Siems 2014, Part II 'Extending the Methods of Comparative Law' (p. 95-187) and most notably chapter 7 'Numerical comparative law' (p. 146-187). Since 2013 with its own journal Comparative Legal History, published with Hart, Oxford. 
For the comparatist, information and sources on legal history are generally more readily available than for other forms of law-in-context approaches. In traditional legal doctrine, many books will include some historical chapter or at least historical references to the origins of some legal concepts, legal rules, legal construction, etc. A historical study will inevitably also use sociological, economic, psychological, and/or other context data. In this way it may encompass, on occasion, a full law-in-context approach.

Historical comparisons may not only explain the origins and reasons for the law as it is today in that society, in some cases they may reveal that similar rules or approaches to law we find in one legal system have been present in another in the past, whereas the current law or views in the latter are different today. Differences may then appear to be just differences in stages of development of legal systems, or differences as to the outcome of ongoing tensions between two opposite views which remain latent in the compared societies, one view taking priority in one society, at least for some time, whereas the other view has become dominant in another legal system (a little like the victories and losses of 'right wing' and 'left wing' political parties in parliamentary elections in the Western world).

Example: In contract interpretation it looks like England, France and Germany are taking rather diverging positions as to what determines the meaning of the contract. In England it is (only) the text of the agreement that counts, in France the subjective will of the contracting parties, and in Germany an 'objectivated' will (what each party could reasonably have understood the intention of the other contracting party was). A historical research, however, reveals that the (French) subjective will theory was dominant in Germany in the second half of nineteenth century and obtained a central position in English law in about the same period, whilst a more objective approach to interpretation became popular among French lawyers by the end of eighteenth century. Actually, each of those approaches to contract law happens to have held a strong position in each of those countries at some time in history. It is mainly a matter of historical coincidence, which 'explains' the differences among the compared legal systems in a more recent past. $^{24}$

The historical method may, thus, as it appears from this example, reveal other similarities and/or differences at a deeper level, compared to what transpires from an analysis at the surface level. ${ }^{25}$

\subsection{The common-core method}

By the end of nineteenth century and early twentieth century, under the influence of the positive sciences, comparative lawyers wanted to find out which legal

24 For a more elaborate analysis: Van Hoecke 2004, p. 81-190.

25 For a historical analysis of cultural differences that explain the different approaches to commercial law in England and France, see Foster 2007, most notably at p. 269-277. 
concepts, legal rules and legal institutions all societies had in common. ${ }^{26}$ This ambition was soon reduced to the 'civilized countries' at the 'same level of development', but even that proved to be not very realistic. Hence, not much research results came out.

In the second half of the twentieth century, new initiatives were taken with the aim of finding a common core among legal systems in some area. New was the focus on how the different legal systems were solving cases rather than on their legal rules and concepts. The largest research project was carried out at Cornell University between 1957 and 1967, in the area of the formation of contracts. ${ }^{27}$

In Europe, the creation and development of the European Union together with tendencies to harmonize law within the EU stimulated research into the common core of law in Europe, to be identified within each of the member states. As a kind of follow-up of the Cornell project, the 'Trento Common Core Project' was set up in Italy by Ugo Mattei and Mauro Bussani. It was more ambitious: 'The ambition of the work in which we are engaged here in Trento is a considerable broadening of the scope of the Cornell project. We are seeking the common core of the bulk of European private law, as divided in the general categories of contract, tort and property.' ${ }^{28}$

The 'Ius Commune Casebooks for the Common Law of Europe' were also set up in the nineties, in view of 'uncovering common principles already underlying existing laws' and to 'enable students from across Europe and beyond to study the same leading cases and materials'.

Also in judicial and legislative practice at the European level, some common-core comparative research has been carried out (Pescatore 1980; Van Der Mensbrugghe 2003).

So, looking for the common core of many areas of law is done in legal practice (European administration, legislation and court practice), in legal education and in legal scholarship. Of course, looking for a common core also ends up in pointing to differences. Moreover, the increase in member states, most notably after 2004, when it jumped from 15 to 25 states, made it increasingly difficult to encompass all member states in such a research, so that for instance the Ius Commune Casebooks are mainly focusing on the three main legal systems for private law, England, France, and Germany (Beale et al. 2010, p. vii).

The common-core method is largely based on the functional method, to some extent combined with the law-in-context method. What is specific to the common-core method is that one looks for a common core in view of the (possible) harmonization of a certain part of the law. In Europe this is a dynamic process,

E.g., the works of Hermann Post (1839-1895): Post 1876 and 1884. See also Lyall 2008.

Schlesinger 1968 (2 volumes). Comparatists from the following countries participated in it: US, India, Australia, France, Germany, Italy, and Switzerland.

Presentation of the project at the first general meeting on July $6^{\text {th }}, 1995$ at http://www. common-core.org/index.php?view=article\&catid=34\%3Athe-project\&id=46\%3Athe-projectdelivered-at-the-first-general-meeting-on-july-6-1995 (last consulted on July 13th, 2014). See also Bussani \& Mattei 2000, p. 29-48. 
both top-down through European rules and judicial decisions and bottom-up through legal education and legal scholarship.

The common-core method looks for commonalities and differences between legal systems in view of the question to what extent harmonization on certain points would be possible among the compared legal systems or the question how a European rule, for instance, could be interpreted in such a way that it fits best the different national traditions.

\section{Levels of comparison}

'Levels of comparison' may be distinguished in various ways, comparing law from different perspectives. The levels on which the law is made and practised geographically (e.g., international, European, state, sub-state) will as such also influence the possible, or at least most evident, levels of comparison. ${ }^{29}$

\subsection{Macro and micro level}

The most classical one is the distinction between macro and micro level, comparing legal systems as distinguished from comparing more concrete rules and legal solutions to societal problems in different legal systems.

A peculiar case is the comparison of EU law with national laws. As the structure of both types of legal system, and also their underlying objectives, are different, this will influence the methods for comparison.

Renaud Dehousse gave as an example the disintegrative impact of EU law on national insurance policies, caused mainly by the diverging regulatory objectives pursued at each level: market integration for the EU, regulation of the insurance market at the national level (Dehousse 1994, p. 770). This implies that the functional, structural and analytical method should be carried out at a deeper level, where those more fundamental differences between the compared legal systems and regulations are taken into account. Also, the structural interdependence of both legal systems prevents the researcher from comparing them as if they were separate and independent units. 'Cross-level comparisons', argues Dehousse, 'should be explicitly concerned with their interaction, and try to encompass the two levels within one single analysis' and 'the exercise is indispensable: in a complex situation, the analyst cannot simply assume a degree of simplicity that no longer exists' (Dehousse 1994, p. 772).

Hence, this will often lead to a combination of different methods to be used in such a cross-level comparison. A typical example is the comparison of the EU institutions and decision-making processes with the traditional separation of powers structures in the nation states: parliament, government, courts. In order to understand the differences one will have to analyse the diverging functions 
of those institutions at both levels (functional method), analysing the different competences of each body in order to draw a full picture of similarities and differences (analytical method) whilst also analysing the whole framework and the relations among the different bodies (structural method) and, finally, putting all this in a historical perspective (historical method).

\subsection{Underlying general and professional legal cultures (or traditions)}

Also, located at a deeper level are comparisons as to legal culture ${ }^{30}$, legal argumentation (Bomhoff 2012), judicial decision making (Lasser 2004), styles of legal writing, diverging approaches to legal sources (MacCormick \& Summers 1997; Komarek 2012) and to statutory interpretation (MacCormick \& Summers 1991) (e.g., the use of travaux préparatoires), the role of legal doctrine, the respective role of the legal professions (e.g., Van Caenegem 1987), the role of form in law in relation to substance (Atiyah \& Summers 1987). Such comparative research has a strong theoretical dimension and tries to draw the background against which legal systems are understood and applied by those working in those legal cultures. The methods used for comparison at this level will mainly be analytical and historical, often revealing hidden world views, which strongly orientate the attitude towards the law.

Even if such underlying legal cultures and world views are not part of the positive law as such, they mostly have a decisive influence on the final content of the law as applied in practice. ${ }^{31}$

\subsection{Law in action vs law in the books}

Indeed, law in action may be (quite) different from law in the books. Most lawyers are well aware of this conclusion. That is why a comparison at the level of rules has to be complemented by, or in some cases started with, a comparison of judicial decisions. In some cases, such as very recent legislation or unavailability of other sources in a language one has access to, comparison will be limited to the level of legislation. However, in any substantive research in comparative law, both legislation and case law will have to be studied, as, in all legal systems, common law and civil law alike, they are both of decisive importance for knowing the law. ${ }^{32}$ This may show how diverging rules and doctrinal constructions may lead to similar decisions or how similar rules and/or doctrinal constructions may lead to diverging practical solutions. The main reason for this is that, especially in hard cases,

30 'Legal culture' is used in a broad sense, encompassing tradition, usages, world view, paradigmatical legal frameworks and anything which is not 'law' in the strict sense but influences legal thinking.

31 See, e.g., for explaining a diverging application of the same European rules in England and Italy by the influence of tradition Nebbia 2000.

32 When, a century ago, Roscoe Pound published his famous paper 'Law in Books and Law in Action' (1910) he mainly commented, sometimes approving, sometimes disapproving, on the way judges, public prosecutors and the police deliberately did not follow the written law. He considered it the work of lawyers 'to make law in the books such that the law in action can conform to it' (p. 86). 
judges first see a desirable solution for the case at hand, which, afterwards, they try to construct on the basis of the legal tools available within their legal system. However, the specific doctrinal constructions of a legal system and/or underlying paradigmatic views may block certain outcomes and facilitate other ones, as appears, for instance, from the example of the interpretation of contracts in section 5.4 below.

\subsection{Surface level vs deep level}

A more thorough look at superficial similarities and/or differences among legal systems may reveal that adequate comparison has, indeed, to take place at a deeper level of doctrinal construction or paradigmatic framework. Actually, Ernst Rabel considered it to be the aim of comparative law to go to that deeper level in order to get a true understanding of the law (Rabel 1924).

\section{Example 1: International private law rules on jurisdiction}

Ralf Michaels has shown how not only rules are different in the US and Europe as to deciding which courts have jurisdiction when several countries may be involved, but moreover

'they think differently about how to apply jurisdiction and they even think differently about what jurisdiction is. Americans and Europeans disagree on the answers because they disagree on the relevant questions' (Michaels 2006, p. 2011). ${ }^{33}$

For example,

'although territoriality and state boundaries are central to both U.S. and European thinking about jurisdiction, they play different roles in each paradigm. In the domestic U.S. paradigm, the role of boundaries is one of delimitation. The power of a court goes to the state's boundaries, not beyond them. It is fair to force a defendant into a court in the state with minimum contacts, but not beyond its boundaries. (...) By contrast, the role of state boundaries in the international European paradigm is one of allocation: the locus of an event or a party defines the place that has jurisdiction in a multilateral fashion' (Michaels 2006, p. 1058).

This means that an adequate comparison has to take place at the level of the underlying paradigms and not only at the levels of legislation or case law.

\section{Example 2: The interpretation of contracts}

In France, the Cour de cassation has, for more than two centuries, considered the interpretation of contracts a matter of 'fact' not of law and, hence, left this to the lower courts. As a result, it escapes the control of the Cour de cassation, which only controls the correct application of the law, not the reality of facts. However, in order to be able to control such interpretations this court worked out a theory of 'dénaturation de l'acte', which assumes that texts may have a 'clear meaning' on

33 He defines the American paradigm as 'vertical, unilateral, domestic, and political' and the European one as 'horizontal, multilateral, international, and apolitical'. 
their own, so that any 'diverging' interpretation would be incompatible with the 'real meaning' of this text. If judges depart from this 'obvious meaning' the Cour de cassation will quash the decision. French doctrinal legal writing concentrates on this problem rather than on the interpretation methods and reasoning by lower courts outside the realm of an alleged 'dénaturation de l'acte'. No other legal system seems to have a comparable approach, due to the lack of 'cassation' and full reconsideration of the case or to different theories (there is no 'denaturation' theory in any of the other countries where the Napoleonic code was introduced). In Germany, discussions are focusing on the, rather diverging, articles in the civil code on the interpretation of contracts ( $\$ 157 \mathrm{BGB})$ and of the 'declaration of will' for any legal act ( $\$ 133 \mathrm{BGB})$.

In England, the interpretation of contracts is not a subject in its own right, but is discussed in other contexts such as the question on whether there was 'consideration'. However, the concept of 'consideration' is unknown in civil-law countries and typically linked to the common-law (business) conception of 'contract'.

This means that any comparison at the surface level of legislation, case law and legal doctrine is virtually impossible or meaningless. Comparison will have to be carried out at a deeper (paradigmatic) level of underlying views and theories on meaning and on interpretation. ${ }^{34}$

When comparing the law in radically different legal cultures, it is obvious that meaningful comparison will only be possible at the deeper level of the underlying cultures and not at the surface level of rules and concepts. Here, surface level comparative law inevitably turns into deep level comparative law and becomes mainly legal anthropology.

\subsection{Doctrinal framework vs underlying legal culture}

\subsubsection{Three basic conceptual frameworks in the world}

In private law, three conceptual legal frameworks have been very influential worldwide: the common law ${ }^{35}$, the French Code civil and the German Bürgerliches Gesetzbuch. Virtually all legal systems of nation states use one of them or a combination of two or more of them.

Through colonization, the English common law was spread over North America, Australia and New-Zealand, parts of Africa and Asia. In Europe, its influence has been limited to Wales, Ireland and, to a lesser extent, Scotland. After independence, the legal systems of the Latin American states were largely based on Roman law and French civil law. As from the twentieth century, this continent has seen a growing influence of the common law.

35 See on the territorial expansion of the common law: McPherson 2007, ch. 8, p. 295-325. 
'The result of this is a mosaic of highly diverse legal systems which, even if located in the circle of the "civil law" family, show a special coloration with its own and particular characteristics' (Kleinheisterkamp 2006, p. 300).

It has not led to conceptually rebuilding the legal framework of civil law in the Latin American countries, but to transplanting practical legal solutions from other legal traditions wherever it seemed useful.

In Africa, the former French, Belgian and Portuguese colonies largely inherited the Code Napoléon. Only South Africa takes a special position with its inheritance of Roman-Dutch law, combined with common law.

In the Islamic countries, parts of the civil law principles are derived from the Quran, but otherwise, former colonizers have been influential, such as France in the Maghreb countries. Other countries, such as Turkey, largely imported a European Code (the German BGB in this case).

In Russia, after 1991, legal doctrine had to a large extent to make a new start, within a new paradigmatic framework. The need for rapid legislative changes made the Russian draftsmen look for inspiration in the Western European Codes (Reid 1998, p. 43). Before the Russian revolution, until the mid-nineteenth century, most law professors were German, the language of education being Latin or German. The legal doctrine, which developed during the nineteenth and early twentieth century had been eradicated by the 1917 communist Revolution. Until the early nineties of the twentieth century, the civil law was first completely dominated by communist ideology and, later on, increasingly tried to combine these ideological premises with some degree of meeting the needs of social reality. This has led to an incoherent legal doctrine. ${ }^{36}$ Moreover, parts of the traditional civilian matters, such as granting a flat or eviction of a flat (by the public authorities) were governed by administrative law, hence limiting the scope of civil law.

\section{As for East Asia,}

' $\mathrm{t}$ ] he modern legal systems of Japan, Korea and China were once all shaped

by the reception of Western legal models, albeit to varying degrees and in a variety of ways' (Kitagawa 2006, p. 259).

These Western legal models were mainly German. The first Chinese Civil Code was enacted under the Qin Dynasty, in 1911. It was drafted by Japanese experts, who took over the German Civil Code. Recent codes on Contract Law (1999), Property Law (2007) and the Law of Obligations (2009) were all mainly influenced by German law, with some elements of the common law.

The common law has spread over parts of Asia too, most importantly in India. 
Central and Eastern European countries took up the Roman law tradition again, after a few decades of communism in the second half of twentieth century. Moreover, in the 1990s, in their desire to join the European Union, they were keen to adopt, as much as possible, Western European law for modernizing their own private law.

The Nordic countries in Europe never took over French, German or English law, but their doctrinal framework has largely been influenced by German legal scholarship (Husa, Nuotio \& Pihlajamäki 2007, p. 9).

In Europe today, all legal systems are mixed ones. The Netherlands, for instance, started with the Code Napoléon in 1804 and basically kept it in 1838, when enacting their Burgerlijk Wetboek. Later on, German legal doctrine has been more influential than in the other countries that followed the Code civil tradition. This resulted in a new Burgerlijk Wetboek in force as from 1992 (most parts having been finished many years before). In the course of the last few decades there is, in The Netherlands, a notable influence of Anglo-Saxon doctrine, both English and American.

Through EU law, but also European Human Rights law, concepts from French and German legal doctrine have entered the other legal systems, such as the (continental) good faith principle in the UK and Ireland, or the (German) proportionality principle in the other member states. Of course, this doesn't necessarily imply a similar use or interpretation of these principles in the countries to which they travel (see e.g., Teubner 1998, p. 11-32).

\subsubsection{With varying application according to the local legal culture}

Conceptual frameworks are one thing, the content of the law (values, principles, rules) and the attitude towards the law are another.

Of course, concepts cannot be completely isolated from rules or from their underlying principles. Property, marriage, leasing, contract, servitude or easement, have some common core of meaning all over the world, even if differences may be sometimes quite important (e.g., acceptance or not of homosexual marriage or of polygamous marriage). However, the larger cultural framework may give a quite different content, for instance, to a rule in Congo, which had been literally copied from the Belgian Civil code (e.g., rejecting monogamy). Japanese civil law is not German, notwithstanding the use of German doctrine, as informal rules still play an important role when it comes to (not) applying the law (Kitagawa 2006, p. 251-253).

Also, within the same legal system, old traditions may make new law to be interpreted in such a way that it blocks all change. ${ }^{37}$

This deeper level of the underlying cultural differences is of utmost importance for correctly judging similarities and differences at the surface level, most nota-

37 See the, already mentioned, example of diverging application of the same European rules in England and Italy by the influence of tradition, as analysed in Nebbia 2000. 
bly, but not exclusively, when legal systems from states belonging to rather different cultural traditions are compared.

\section{Tertium comparationis}

In order to compare, it has been emphasized, we need a tertium comparationis. ${ }^{38} \mathrm{We}$ should not look at a foreign legal system with the eyes and doctrinal framework of our own legal system, but try to transcend it, by using external 'neutral' elements for comparing legal systems: 'the comparatist must eradicate the preconceptions of his native legal system' (Zweigert \& Kötz 1998, p. 35). Indeed, describing law is not an 'objective' activity, it doesn't offer 'pure facts' everybody would see in the same way, like a flower as compared to a tree, or a dog as compared to a cat. ${ }^{39}$ Looking at concepts, rules, institutions, and the like in other societies will, at least at a first stage, always happen at the background of one's own legal system and doctrinal framework. What comparatists mainly wanted to emphasize with the tertium comparationis is the need to be aware of this bias and to try to get out of one's own conceptual framework. What this 'tertium comparationis' could be and how to find it, remains less clear. Should one compare apples with oranges by reference to banana's, or to pears and lemons? Or to an abstract concept of 'fruit'? What could be the tertium comparationis when comparing the repudiation of a wife in Islamic law with divorce in Western law?

Actually, what has initially been a well-founded warning against biases in comparative research has, erroneously, been perceived as part of comparative method. There is no reason why comparative research should be limited to legal phenomena with common characteristics or to legal systems 'at the same stage of development', as Esin Örücü has rightly claimed (Örücü 2006, p. 443). As comparative law has largely developed with the aim of improving one's own legal system, it is understandable that this kind of research required some level of comparability in order to be useful. However, comparative research carried out with other aims, such as understanding quite different legal cultures, cannot and should not use such conditions.

Nils Jansen analysed the concepts and methods of comparison in historical linguistics and comparative religion and concluded, as for the latter:

'Thus, tertia comparationis cannot be defined as part of the method; comparison must remain open for new insights. Nevertheless, as a result of successful comparisons, the discipline has - perhaps unconsciously - developed a comparative second-order language describing the concepts that constitute the different religions' beliefs. It has become highly useful for analysing the

38 The concept has already been used by Ernst Rabel in 1924: Rabel 1924.

39 Although even these objects are only seen in the same way within cultures who know these objects, where cats and dogs are domesticated, etc. The way we see things is always determined by our own experience and world view. Hence, for human beings there are no 'objective facts' independent from human cultures. 
complex commonalities and differences of religion; all in all it represents a

large body of comparative knowledge' (Jansen 2006, p. 330).

Above, when discussing the methods of comparative legal research, we have seen how, in most cases, comparatists focusing on methodology have tried to develop such a, relatively neutral, second-order language describing the concepts that constitute the different legal systems, even if in applied comparative research mostly first-order languages are used.

Instead of looking for tertia comparationis, legal comparatists should, indeed, through their research, develop such a comparative second-order language. ${ }^{40}$ Actually, what is presented as tertium comparationis is sometimes in fact such a second-order language ${ }^{41}$ It is true that legal systems can only be correctly understood in their own language, from their own internal perspective (Valcke 2012, p. 22-48), but in order for comparative law to develop as a discipline some kind of second-order language(s) will have to be worked out.

Only in case of harmonization of law a new common (first-order) legal language has to be developed. ${ }^{42}$

\section{Conclusion}

The comparatist disposes of a pluralist toolbox containing the following methodological opportunities:

- The functional method is looking at the actual societal problem (e.g., a train accident) and the way this is solved in different jurisdictions (most notably compensating the victims for their damage) along similar or different roads (e.g., contract liability or tort liability) and with similar or different results (e.g., compensation or not for pure economic loss). The focus is on the societal problem and the actual result of the legal approach to that problem.

- The analytical method is analysing (complex) legal concepts and rules (e.g., ownership) in different legal systems in such a way that common parts and differences are detected (claims, liberties, competences, etc.). The use of 'ideal

40 Here, I'm not going into the discussion on the (im)possibility of creating a 'meta-language' (see Kjær 2004). Every discipline develops its own concepts. These 'second-order languages' are, of course, not full languages like Esperanto, but coherent conceptual tool kits. In a way, Roman law functioned in the Middle Ages as a second-order language for interpreting local customary law.

41 E.g.: 'I had been able to determine through previous work that mismatches between subjective intention and objective declaration, or the concern to consecrate yet also discipline party intention, were considered legal issues under English law and French law alike. Those issues therefore arguably provided appropriate tertia comparationis for investigating the English and the French law of, respectively, contractual mistake and contractual interpretation, even though they might prove inadequate for the purpose of investigating other areas of English and French contract law' (Valcke 2012, p. 33). This shows how a second-order language may partly overlap with the legal languages of the compared legal systems. Also, it shows how some concepts may be useful at a meta-level for some specific comparison, without having some broader, let alone 'universal' validity.

42 For a good overview of the problems related to such 'harmonized' legal language, see Dannemann 2012. See also, in the same volume, the contribution of Claes and De Visser (2012, p. 143-169). 
types' makes it possible to rank those legal concepts, rules, institutions, on a scale according to the degree of fitting with the core characteristics of the 'ideal type'.

- The structural method is focusing on the framework of the law or of the elements reconstructed through an analytical approach. This is not the structure of each of the compared legal systems, but just one way of looking at them, which proves to be revealing for answering the research question.

- The historical method will almost always be a necessary part of the methods used, for understanding differences and commonalities among legal systems and for determining their degree of belonging to a deeply rooted tradition or rather to accidental historical events.

- The law-in-context method has inevitably also a historical dimension but focuses on the law's current societal context, including, where appropriate, culture, economy, psychology, religion, etc. It studies a much broader context when compared to the functional or analytical method and implies the use of (results from) other disciplines.

Most of those methods will make the researcher move from a surface level of comparison to a deeper level: diverging types of 'right' included in complex legal concepts, rules and institutions, underlying world views, a detected common structural framework behind apparent differences, elements in history that are weakening the strength of seemingly opposed and irreconcilable approaches, etc.

One may also distinguish other levels of comparison, each of them implying the use of some method(s) rather than other ones.

A first distinction is the one between micro and macro comparison: studying concrete legal problems or concrete legal concepts, rules or institutions, as compared to a broader approach as to, for instance, the overall organization of the state, or the organization of social security.

A second distinction is the one between comparing the content of the law versus comparing doctrinal frameworks relatively independently from that content (a more 'technical' comparison).

It has to be repeated: the choice of method or level for comparison will mainly depend on the research question(s) guiding the research project.

Different aims often imply different methods, be it not always. For instance, the different aims mentioned above, in section 1, of improving domestic law in France by the end of the nineteenth century when compared to harmonization initiatives in the EU by the end of the twentieth century, basically have led to the use of similar methods. In both cases, legal scholars have been looking for the 'better solution'. According to Lambert, scholarly research should be able to prove the superiority of some legislation over others and should, hence, be chosen as 'droit commun législatif' (Lambert 1900, p. 242; also: Jamin 2000, p. 733-751). Today the better solution approach is, explicitly or implicitly, underlying many comparative 
law research projects. This is most notably the case when economic analysis of law is used within a comparative law context. ${ }^{43}$

Are the methods listed above the only possible ones? For instance, what about legal transplants? Legal transplants are rather an aim or a result, not a comparative method in its own right. ${ }^{44}$ Successful legal transplants will require a law-incontext method. What seems to work well in another legal system may indeed fail to do so in one's own legal system because of a different context. The import of European family law in most African countries during colonization times, and kept after that, is a clear example of failed transplants because of a quite different cultural context (Van Hoecke 2012). Hence, just copying foreign law could hardly be considered to be a 'method'. It is rather the typical example of lack of method in comparative law.

What about social-sciences methodology? A law-in-context approach may require the use of at least some methods of the used social sciences (historical, economic, political, sociological, anthropological,...) unless the relevant information is already available in published research results. The social-science methods will then be an instrument within the context of one of the chosen comparative methods. Even at the level of the sheer description of foreign law one may, for instance, want to get a full and correct view of the law as it works in practice by taking interviews of relevant stakeholders and not limit oneself to consulting legislation, published case law and legal doctrine (or in case one doesn't master sufficiently the local language). However, it still will remain part of a description of foreign law, which in turn will be part of some of the mentioned methods within the context of scholarly comparative legal research.

In this paper, I have tried to identify six methods which have been used in comparative research, in a broad sense, until now and which cannot be reduced to each other. This doesn't exclude that other methods or combination of methods with other names would be possible, but for the time being these seem to cover the whole current methodology of comparative legal research. new either. Christophe Jamin quotes the French scholars Boissonade and Saleilles, who already in the $19^{\text {th }}$ century talked about 'a real international bazar' (of ideas) in this context (Jamin 2000, p. 748).

44 In legal theory the study of legal transplants may be a way, a 'method' for research on legal change (Graziadei 2009). 


\section{References}

\section{Adams \& Griffiths 2012}

M. Adams \& J. Griffiths, 'Against “Comparative Method": Explaining Similarities and Differences', in: M. Adams \& J. Bomhoff, Practice and Theory in Comparative Law, Cambridge: Cambridge University Press 2012, p. 279-301.

\section{Antokolskaja 2007}

M. Antokolskaja, 'Comparative Family Law: Moving with the Times?', in: E. Örücü \& D. Nelken (eds.), Comparative Law. A Handbook, Oxford: Hart Publishing 2007, p. 241262.

\section{Arnaud 1973}

A.J. Arnaud, Essai d'analyse structurale du Code civil français, Paris, Librairie générale de droit et de jurisprudence 1973.

\section{Atiyah \& Summers 1987}

P.S. Atiyah \& R.S.Summers, Form and Substance in Anglo-American Law, Oxford: Clarendon Press 1987.

Beale et al. 2010

H. Beale et al., Cases, Materials and Text on Contract Law, Oxford: Hart Publishing 2010, p. vii.

\section{Boele-Woelki, Dethloff \& Gephart 2014}

K. Boele-Woelki, N. Dethloff \& W. Gephart (eds.), Family Law and Culture in Europe: Developments, Challenges and Opportunities, Mortsel/Cambridge: Intersentia 2014.

\section{Bomhoff 2012}

J. Bomhoff, 'Comparing Legal Argument', in: M. Adams \& J. Bomhoff (eds.), Practice and Theory in Comparative Law, Cambridge: Cambridge University Press 2012, p. 74-95.

\section{Brouwer \& Hage 2007}

P.W. Brouwer \& J. Hage, 'Basic Concepts of European Private Law', European Review of Private Law 2007, p. 3-26.

Bussani \& Mattei 2000

M. Bussani \& U. Mattei, 'Le fonds commun du droit privé européen', Revue international de droit comparé 2000, p. 29-48.

\section{Cameron 1977}

G.D. Cameron, 'The Development of Individual Property Rights Under Soviet Law', American Business Law Journal 1977, p. 333-355.

\section{Claes \& De Visser 2012}

Monica Claes and Maartje de Visser, 'Reflections on comparative method in European constitutional law', in: M.Adams \& J.Bomhoff, Practice and Theory in Comparative Law, Cambridge: University Press, 2012,143-169.

\section{Dannemann 2012}

G. Dannemann, 'In Search of System Neutrality: Methodological Issues in the Drafting of European Contract Law Rules', in: M. Adams \& J. Bomhoff, Practice and Theory in Comparative Law, Cambridge: Cambridge University Press 2012, p. 96-119.

\section{Dehousse 1994}

R. Dehousse, 'Comparing National EU Law: The Problem of Level of Analysis', Am.Jo. Comp.L. 1994, p. 761-781.

\section{Flanagan \& Ahern 2011}

B. Flanagan \& S. Ahern, 'Judicial Decision-Making and Transnational Law: A Survey of Common Law Supreme Court Judges', International \& Comparative Law Quarterly 2011, p. 1-28. 


\section{Foster 2007}

N.H.D. Foster, 'Comparative Commercial Law', in: E. Örücü \& D. Nelken, Comparative Law: A Handbook, Oxford: Hart Publishing 2007, p. 263-285.

\section{Frändberg 1987}

Å. Frändberg, 'Systematics of Legal Concepts', Scandinavian Studies in Law 1987-31, p. 83-115.

\section{Glenn 2006}

H. Patrick Glenn, 'The Aims of Comparative Law', in: J.M.Smits (ed.), Elgar Encyclopedia of Comparative Law, Cheltenham: Edward Elgar 2006,p. 57-65.

\section{Graziadei 2003}

M. Graziadei, 'The Functionalist Heritage', in: P. Legrand \& R.Munday (eds.), Comparative Legal Studies: Traditions and Transitions, Cambridge: Cambridge University Press 2003, p. 100-127.

\section{Graziadei 2009}

M. Graziadei, 'Legal Transplants and the Frontiers of Legal Knowledge', Theoretical Inquiries in Law 2009, p. 723-743.

\section{Hart 1961}

H.L.A Hart, The Concept of Law, Oxford: Oxford University Press 1961, p. 77-96.

\section{Hedenius 1975}

I. Hedenius, 'Analysen av äganderettsbegreppet', in: B. Belfrage \& L. Stille (eds.), Filosofi och rättsvetenskap, Lund: Doxa 1975, cited by Frändberg 1987, p. $83 \mathrm{ff}$.

\section{Hohfeld 1919}

W.N. Hohfeld, Fundamental Legal Conceptions, as Applied in Judicial Reasoning, New Haven: Yale University Press 1919 (first published in the Yale Law Journal, 1917, reprinted Westport, CT: Greenwood Press 1978).

\section{Husa, Nuotio \& Pihlajamäki 2007}

J. Husa, K. Nuotio \& H. Pihlajamäki (eds.), Nordic Law - Between Tradition and Dynamism, Antwerp/Oxford: Intersentia 2007, p. 9.

\section{Husa 2011}

J.Husa, 'Comparative Law, Legal Linguistics and Methodology of Legal Doctrine' in: M.van Hoecke, ed., Methodologies of Legal Research. Which Kind of Method for What Kind of Discipline?, Oxford: Hart 2011, p. 209-228.

\section{Husa 2013}

J. Husa, 'Functional Method in Comparative Law - Much Ado About Nothing?', Eur. Rev.Priv.Law 2013, p. 4-21.

\section{Izorche 2001}

M.L. Izorche, 'Propositions méthodologiques pour la comparaison', Revue international de droit comparé 2001, p. 289-325.

\section{Jamin 2000}

C. Jamin, 'Le vieux rêve de Saleilles et Lambert revisité. A propos du centenaire du congress international de droit comparé de Paris', Revue international de droit comparé 2000, p. 733-751.

\section{Jansen 2006}

N. Jansen, 'Comparative Law and Comparative Knowledge', in: M. Reimann \& R. Zimmermann (eds.), The Oxford Handbook of Comparative Law, Oxford: Oxford University Press 2006, ch. 9, p. 305-338.

\section{Kitagawa 2006}

Z. Kitagawa, 'Comparative Law in East Asia', in: M. Reimann \& R. Zimmermann (eds.), The Oxford Handbook of Comparative Law, Oxford: Oxford University Press 2006, ch. 7, p. 237-260, at p. 251-253. 


\section{Kjær 2004}

A.L. Kjær, 'A Common Legal Language in Europe?', in: M. Van Hoecke (ed.), Epistemology and Methodology of Comparative Law, Oxford: Hart Publishing 2004, p. 377-398.

Kleinheisterkamp 2006

J. Kleinheisterkamp, 'Development of Comparative Law in Latin America', in: M. Reimann \& R. Zimmermann (eds.), The Oxford Handbook of Comparative Law, Oxford: Oxford University Press 2006, ch. 8, p. 161-301.

\section{Komárek 2012}

J. Komárek, 'Reasoning with Previous Decisions', in: M. Adams \& J. Bomhoff (eds.), Practice and Theory in Comparative Law, Cambridge: Cambridge University Press 2012, p. 49-73.

\section{Lambert 1900}

E. Lambert, 'Une réforme nécessaire des etudes de droit civil', Revue inter. enseignement 1900, p. 242, 237.

\section{Lasser 2004}

M. Lasser, Judicial Deliberations: A Comparative Analysis of Judicial Transparency and Legitimacy, Oxford: Oxford University Press 2004.

\section{Lemmens 2012}

K. Lemmens, 'Comparative Law as an Act of Modesty: A Pragmatic and Realistic Approach to Comparative Legal Scholarship', in: M. Adams \& J. Bomhoff, Practice and Theory in Comparative Law, Cambridge: Cambridge University Press 2012, p. 302-325. Lyall 2008

A. Lyall, 'Early German Legal Anthropology: Albert Hermann Post and His Questionnaire', Journal of African Law 2008, p. 114-138.

\section{MacCormick \& Summers 1997}

N.D. MacCormick \& R.S. Summers (eds.), Interpreting Precedents: A Comparative Study, Brookfield, VT: Aldershot/Dartmouth: Ashgate 1997.

\section{McPherson 2007}

B. McPherson, The Reception of English Law Abroad, Brisbane: Supreme Court of Queensland Library 2007, ch. 8, p. 295-325.

\section{Merryman 1999}

J.H. Merryman, 'Comparative Law and Scientific Explanation', in J.H. Merryman, The Loneliness of the Comparative Lawyer and Other Essays in Foreign and Comparative Law, The Hague/London/Boston: Kluwer Law International 1999, p. 478-502 (first published in J.N. Hazard \& W.J. Wagner (eds.), Law in the USA in Social and Technological Revolution, Brussels: Bruylant 1974, p. 81-104).

\section{Meuwese \& Versteeg 2012}

A. Meuwese \& M. Versteeg, 'Quantitative Methods for Comparative Constitutional law', in: M. Adams \& J. Bomhoff (eds.), Practice and Theory in Comparative Law, Cambridge: Cambridge University Press 2012, p. 230-257.

\section{Michaels 2006}

R. Michaels, 'Two Paradigms of Jurisdiction', Michigan Journal of International Law 2006, p. 1003-1069.

\section{Michaels 2006}

Ralf Michaels, 'The Functional Method of Comparative Law', in: M. Reimann \& R. Zimmerman (eds.), Oxford Handbook of Comperative law 2006, ch. 10, p. 340-382.

\section{Nebbia 2000}

P. Nebbia, 'Unfair Terms in Consumer Contracts: An Anglo-Italian Comparison', in: M. Van Hoecke \& F. Ost (eds.), The Harmonisation of European Private Law, Oxford: Hart Publishing 2000, p. 179-188. 


\section{Örücü 2006}

E. Örücü, 'Methodology of comparative law', in: J.M. Smits (ed.), Elgar Encyclopedia of Comparative Law, Cheltenham/Northhampton: Edward Elgar 2006, ch. 41, p. 442454.

Örücü 2007

E. Örücü, 'Developing Comparative Law', in: E. Örücü \& D. Nelken (eds.), Comparative Law: A Handbook, Oxford: Hart Publishing 2007, p. 62.

\section{Pescatore 1980}

P. Pescatore, 'Le recours dans la jurisprudence de la Cour de justice des Communautés européennes à des norms déduites de la comparaison des droits des Etats membres', Revue internationale de droit comparé 1980, p. 337-.

\section{Pospisil 1971}

L. Pospisil, Anthropology of Law: A Comparative Theory, New York: Harper \& Row 1971.

\section{Post 1876}

H. Post, Der Ursprung des Rechts. Prolegomena zu einer Allgemeinen vergleichenden Rechtswissenschaft, Oldenburg: Berndt \& Schwarzer 1876.

\section{Post 1884}

H. Post, Die Grundlagen des Rechts und die Grundzüge seiner Entwickelungsgeschichte: Leitgedanken für den Aufbau einer allgemeinen Rechtswissenschaft auf soziologischer Basis, Oldenburg: A. Schwarz 1884.

\section{Pound 1910}

R. Pound, 'Law in Books and Law in Action', American Law Review 1910-44, p. $12-86$.

\section{Pound 1936}

R. Pound, 'What May We Expect from Comparative Law?', American Bar Association

\section{Rabel 1924} Journal 1936-22, p. 56-60.

E. Rabel, 'Aufgabe und Notwendigkeit der Rechtsvergleichung', Rheinische Zeitschrift für Zivil- und Prozessrecht 1924, p. 279-301, reprinted in H.G. Leser (ed.), Ernst Rabel Gesammelte Aufsätze, vol. III, Arbeiten zur Rechtsvergleichung und zur Rechtsvereinheitli-

\section{Raz 1980} chung 1919-1954, Tübingen: J.C.B. Mohr 1967, p. 1-21.

\section{Reed 2008}

J. Raz, The Concept of a Legal System, Oxford: Clarendon Press 1980, p. 141.

R. Reed, 'Foreign Precedents and Judicial Reasoning: The American Debate and Brit-

\section{Reid 1998} ish Practice', Law Quarterly Review 2008, p. 253-273.

E. Reid, 'The Law of Trusts in Russia', Review of Central and East European Law 1998, p. 43-56.

\section{Rheinstein 1934}

M. Rheinstein, 'Comparative Law and Conflict of Laws in Germany', University of Chicago Law Review 1934-35, p. 232-269.

\section{Sacco 1991}

R. Sacco, 'Legal Formants. A Dynamic Approach to Comparative Law', American Journal of Comparative Law 1991, p. 1-34 (part I) and p. 343-401 (part II).

\section{Saleilles 1911}

R. Saleilles, 'Droit civil et droit comparé', Revue inter. enseignement 1911, p. 22.

\section{Samuel 2001}

G. Samuel, An Introduction to Comparative Law Theory and Method, forthcoming (ch 5, II, p. 78 in the manuscript), with references to J.-M. Berthelot, 'Programmes, paradigms, disciplines: pluralité et unité des sciences sociales', in: J.-M. Berthelot (ed.), 
Epistémologie des sciences sociales, Paris: Presses Universitaires de France 2001, at p. 484, and J.-M. Berthelot, Les vertus de l'incertitude, Paris: PUF 1996, at p. 81.

\section{Samuel 2014}

G. Samuel, An Introduction to Comparative Law Theory and Method, Oxford: Hart Publishing 2014, p. 81-82.

\section{Schlesinger 1968}

R. Schlesinger (ed.), Formation of Contracts: A Study of the Common Core of Legal Systems, New York: Dobbs Ferry 1968 (2 volumes).

\section{Siems 2014}

M. Siems, Comparative Law, Cambridge: Cambridge University Press, 2014.

\section{Teubner 1998}

G. Teubner, 'Legal Irritants: Good Faith in British Law or How Unifying Law Ends Up in New Divergences', Modern Law Review 1998, p. 11-32.

\section{Twining 2007}

W. Twining, 'Globalisation and Comparative Law', in: E. Örücü \& D. Nelken (eds.), Comparative Law. A Handbook, Oxford: Hart Publishing 2007, p. 69-89.

\section{Valcke 2012}

C. Valcke, 'Reflections on Comparative Law Methodology - Getting Inside Contract Law', in: M. Adams \& J. Bomhoff, Practice and Theory in Comparative Law, Cambridge: Cambridge University Press 2012, p. 22-48.

\section{Van Caenegem 1987}

R. van Caenegem, Judges, Legislators and Professors, Cambridge: Cambridge University Press 1987.

Van der Mensbrugghe 2003

F. Van Der Mensbrugghe (ed.), L'utilisation de la méthode comparative en droit européen, Namur: Presses universitaires 2003.

\section{Van Hoecke \& Warrington 1998}

M. Van Hoecke \& M. Warrington, 'Legal Cultures, Legal Paradigms and Legal Doctrine: Towards a New Model for Comparative Law', The International and Comparative Law Quarterly 1998, p. 495-536.

\section{Van Hoecke 2004}

M. Van Hoecke, 'Deep Level Comparative Law', in: M. Van Hoecke (ed.), Epistemology and Methodology of Comparative Law, Oxford: Hart Publishing 2004, p.165-195.

\section{Van Hoecke 2012}

M. Van Hoecke, 'Family Law Transfers from Europe to Africa: Lessons for the Methodology of Comparative Legal Research', in: J. Gillespie \& P. Nicholson, Law and Development and the Global Discourses of Legal Transfers, Cambridge: Cambridge University Press 2012, ch. 10, p. 273-295.

\section{Van Hoecke 2014}

M. Van Hoecke, 'Do "Legal Systems" Exist? The Concept of Law and Comparative Law', in: S. Donlan \& L. Heckendorn Urscheler (eds.), Concepts of Law, Dartmouth: Ashgate 2014, ch. 3, p. 43-57.

\section{Zhdanov 2006}

A.A. Zhdanov, 'Transplanting the Anglo-American Trust in Russian Soil', Review of Central and Eastern European Law 2006, p. 179-231.

\section{Zweigert \& Kötz 1998}

K. Zweigert \& H. Kötz, Introduction to Comparative Law, Oxford: Clarendon Press 1998, p. 35. 